\title{
Effect of Broccoli (Brassica oleracea L. var. italica) Extract on Bleeding Time in Male White Mice (Mus musculus L.)
}

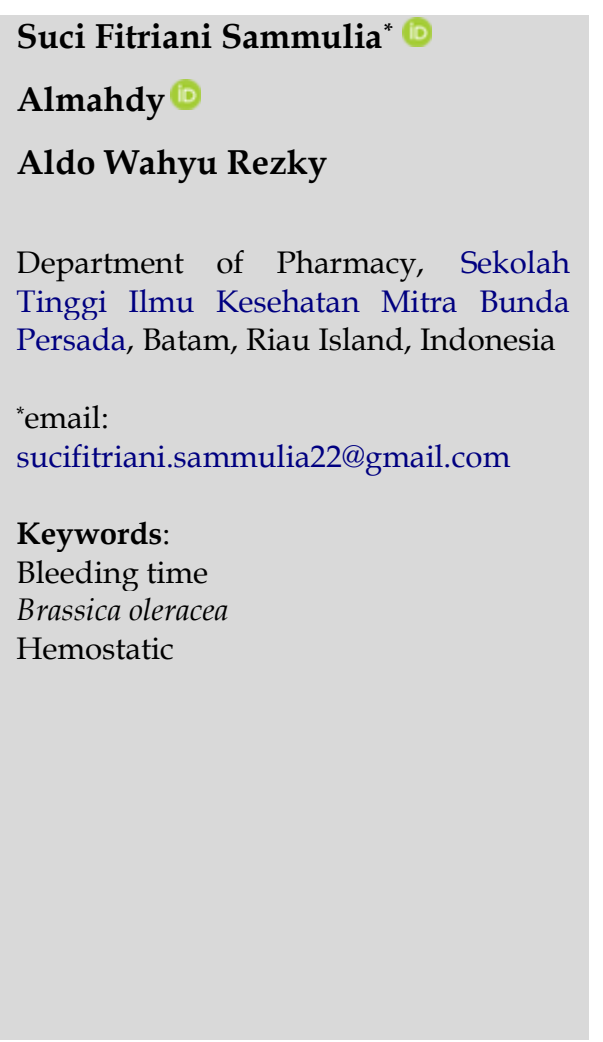

\begin{abstract}
Cessation of bleeding is influenced by many factors including the type of medication used. The use of drugs to stop bleeding can be done in various ways, one of which is the use of traditional medicine. One of the traditional plants that can be used as a stop bleeding is broccoli (Brassica oleracea L. var. italica.) which has a fairly high vitamin $\mathrm{K}$ content, where is efficacious as hemostatic. This study aims to determine the effect of broccoli on the bleeding time of mice tail cuts. The first group was negative control (Na-CMC), the second group was positive control (tranexamic acid), while groups three, four, and five were broccoli extract dose of 20,40, and $60 \mathrm{mg} / \mathrm{kg} \mathrm{BW}$, respectively. All treatments were given orally for seven days. Bleeding time was calculated from the initial blood loss until the blood stopped (tail bleeding I method) and the data were analyzed with the ANOVA one way test and the post hoc Least Significant Difference (LSD) statistical test. The results showed that there were differences in the time to stop bleeding in the treatment control group at a dose of $20 \mathrm{mg} / \mathrm{kg} \mathrm{BW}$ (122.60 \pm 29.535 seconds), $40 \mathrm{mg} / \mathrm{kg} \mathrm{BW} \mathrm{(102.40 \pm 9.607} \mathrm{seconds)} \mathrm{and}$ $60 \mathrm{mg} / \mathrm{kg}$ BW $(90.40 \pm 3.845$ seconds). From these results, it can be concluded that the extract of broccoli at a dose of $60 \mathrm{mg} / \mathrm{kg}$ BW gives the best results as hemostatic, while the effect is almost similar to the positive control group.
\end{abstract}

Received: January $2^{\text {nd }} 2020$

Accepted: February $13^{\text {th }} 2020$

Published: February 27th 2020

(C) 2020 Suci Fitriani Sammulia, Almahdy, Aldo Wahyu Rezky. Published by Institute for Research and Community Services Universitas Muhammadiyah Palangkaraya. This is an Open Access article under the CC-BY-SA License (http://creativecommons.org/licenses/by-sa/4.0/). DOI: https://doi.org/10.33084/bjop.v3i1.1246.

\section{INTRODUCTION}

External bleeding is bleeding originating from an open wound so that it can be seen from a physical examination (Guo \& DiPietro, 2010). Bleeding is a process of bleeding from blood vessels that can cause damage to blood vessel walls caused by trauma or disease (Xu et al., 2019). The normal functioning hemostatic system is important for the life of the organism because if the hemostatic is disrupted, even a small wound can cause life-threatening bleeding (Periayah et al., 2017).

The normal innate hemostatic mechanism of the body is sufficient to repair damage and stop the secretion of blood from these delicate microcirculation vessels (Chen et al., 2018). The body's mechanism in stopping bleeding involves three main steps, including vascular spasm, formation of platelet plugs, and blood coagulation (formation of blood clots) (Sherwood, 2015). Hemostatic failure causes bleeding and is a dangerous clinical problem (Pierce \& Pittet, 2014).

An example of a well-known failure of the hemostatic process is hemophilia. Hemophilia is a very common disease which refers to the tendency to experience severe excessive bleeding (Curnow et al., 2016). In the United States, about 1 in 10,000 people suffer from hemophilia with severe severity. From all the case, four out of five cases are caused by factor VIII deficiency (Sacher, 2012). Wound healing is influenced by many factors including the type of medication used. The use of drugs for wound 
healing can be done with a variety of types and types, one of which is the use of traditional medicine (Guo \& DiPietro, 2010; Saghazadeh et al., 2018). The use or treatment is traditionally increasingly preferred because in general there are fewer side effects as well as drugs from chemicals (Yuan et al., 2016).

Broccoli (Brassica oleracea L. var. italica.) is a family of Brassicaceae that contains good phytochemicals such as glucosinolates, phenolic compounds, fiber and antioxidant compounds such as vitamins $\mathrm{C}$ and $\mathrm{E}$ and minerals ( $\mathrm{Ca}, \mathrm{Mg}$, Se, and $\mathrm{K}$ ) (Raiola et al., 2017). According to United States Department of Agriculture (2012), compared with other vegetables including carrots, cabbage, and spinach, the vitamin K content in broccoli is higher at $101.6 \mathrm{mg}$ or $85 \%$ greater than other vegetables. Based on this background, this study aims to determine the effect of broccoli on the bleeding time of mice tail cuts.

\section{MATERIALS AND METHODS}

\section{Materials and tools}

The material used in this study were broccoli, tranexamic acid (Kalnex $\left.{ }^{\circledR}\right)$, Na-CMC, natrium chloride 0.9\% $(\mathrm{Otsu} \AA)$, ethanol, concentrated hydrogen chloride, Dragendorff reagent, Mayer reagent, 10\% iron (III) chloride, amyl alcohol, chloroform, anhydrous acetic acid, and male white mice (Mus musculus L.) weighing between 20 and $30 \mathrm{~g}$. The tools used in this study include glassware (Iwaki®), hot plate, oven, vacuum rotary evaporator (Heidolph $®)$, analytical scale (Kenko®), stirring rod, stopwatch, and measuring flask (Iwaki®).

\section{Extracting preparation}

Broccoli used in this research was $5 \mathrm{~kg}$ of fresh broccoli obtained from Samarinda market in Batam City, which has been identified in Herbarium of Universitas Andalas, Padang. Broccoli that has been prepared is then washed using running water. After washing, broccoli is cut into small pieces. Broccoli chunks are then dried in the morning sun for three consecutive days. After drying, broccoli is extracted by maceration method using $70 \%$ ethanol for three days while stirring occasionally. The extract obtained was then evaporated using a vacuum rotary evaporator at $40^{\circ} \mathrm{C}$ to obtain a thick extract.

\section{Phytochemical screening}

Alkaloid test

A total of $2 \mathrm{ml}$ of the extract solution was evaporated in a porcelain cup. The residue obtained is then put into a test tube and $5 \mathrm{ml}$ of $2 \mathrm{~N} \mathrm{HCL}$ is added. The solution is then divided into 2 tubes. Tube 1 is added 2-3 drops of Dragendorff reagent, while tube 2 is added Mayer reagent. Positive results of the alkaloid content are indicated by the formation of red brick, red, or orange colors with the Dragendorff reagent, and white or yellow deposits with the Mayer reagent (Auwal et al., 2014).

\section{Saponin test}

As much as $0.5 \mathrm{~g}$ of broccoli extract is added to $0.5 \mathrm{ml}$ of hot water. Cool the mixture first to room temperature then shake vigorously for 10 seconds to produce solid foam as high as $1-10 \mathrm{~cm}$. Then $1 \% \mathrm{HCl}$ is added and waited for 10 minutes. Positive results from the saponin content are shown if the foam does not disappear (Hossain et al., 2013).

\section{Tannin test}

Broccoli extract is boiled with $20 \mathrm{ml}$ of water then filtered with filter paper and then added a few drops of $10 \%$ $\mathrm{FeCl}_{3}$. A positive result of the tannin content is shown if the solution produces a greenish brown or black-blue color (Batool et al., 2019).

\section{Flavonoid test}

As much as $0.5 \mathrm{~g}$ of broccoli extract is added to a small amount of Mg powder and then shaken until mixed. The mixture is then added with a few drops of concentrated $\mathrm{HCl}$. The positive results of flavonoids are marked by the formation of orange, red, or yellow (Panche et al., 2016). 


\section{Animal care and handling}

Test animals used in this study were Swiss Webster male mice selected by purposive sampling with age requirements of around 2-3 months with a body weight of about 20-30 g. The selection of test animals is done by simple random sampling (Samanta et al., 2016). Determination of the sample size of each group is determined based on the Federer calculation formula obtained at least five mice per group for a total of five test groups. The total number of test animals to be used is 25 male mice. Before giving treatment, the test animals were acclimatized for seven days. The treatment of test animals is carried out based on research code of ethics using test animals with protocol number 34040125121242020022800279 issued by Universitas Aisyiyah Yogyakarta.

\section{Provision of test treatment}

After going through the acclimation process, test animals are given treatment based on each test group. The negative control group was given $0.5 \% \mathrm{Na}-\mathrm{CMC}$, the positive control group was given tranexamic acid as much as $102.74 \mathrm{mg} / 20 \mathrm{~g}$ BW. While treatment groups I, II and III, each given a dose of broccoli extract of 20 $\mathrm{mg} / \mathrm{kg} \mathrm{BW}, 40 \mathrm{mg} / \mathrm{kg} \mathrm{BW}$, and $60 \mathrm{mg} / \mathrm{kg} \mathrm{BW}$, respectively.

\section{Bleeding time}

Determination of bleeding time is done by calculating the time needed starting from the wound starting to drip blood until the blood stops dripping from the wound. First the rats' tails were cleaned with $70 \%$ alcohol then cut $1 \mathrm{~cm}$ from the tail end. The cut tail is inserted into a tube containing warm $\mathrm{NaCl}\left(37^{\circ} \mathrm{C}\right)$. The duration of bleeding is calculated using a stopwatch from the onset of blood droplets from injured blood vessels until the blood stops flowing out of the blood vessels (Liu et al., 2012). The time interval from the first drop until the blood stops dripping is the bleeding time.

\section{Data analysis}

The data obtained were analyzed using SPSS version 21. To determine the normality of data distribution, tests were performed using the Shapiro-Wilk test. Homogeneity test was performed using the Levene variant test. Then the Least Significant Difference (LSD) test is performed to see the differences between each treatment group.

\section{RESULTS AND DISCUSSION}

\section{Phytochemical screening}

Phytochemical screening results of broccoli extract indicate that positive broccoli plants contain alkaloids, saponins, tannins, and flavonoids. These results are in line with several previous studies which showed the existence of the compound class (Chauhan et al., 2016; Hussain et al., 2019; Mageney et al., 2017; Raiola et al., 2017). The complete phytochemical screening results are presented in Table I.

Table I. Phytochemical screening results

\begin{tabular}{|c|c|c|c|}
\hline Phytochemical & Reagent & Result & Conclusion \\
\hline \multirow[t]{2}{*}{ Alkaloid } & Dragendorff & $\begin{array}{c}\text { Orange } \\
\text { precipitate }\end{array}$ & + \\
\hline & Mayer & $\begin{array}{c}\text { White } \\
\text { deposit }\end{array}$ & + \\
\hline Saponin & $\begin{array}{c}\text { Water + } \\
\mathrm{HCl}\end{array}$ & $\begin{array}{c}\text { Foaming } \\
\text { over } 10 \\
\text { seconds }\end{array}$ & + \\
\hline Tannin & $\mathrm{FeCl}_{3}$ & $\begin{array}{l}\text { Blackish } \\
\text { brown }\end{array}$ & + \\
\hline Flavonoid & $\mathrm{Mg}+\mathrm{HCl}$ & Yellow & + \\
\hline
\end{tabular}

\section{Bleeding time}

The parameter observed in this test is the bleeding time. The average measurement of bleeding time in the positive control group was $73.80 \pm 6.76$ seconds, while in the negative control was $183.00 \pm 18.193$. The bleeding time of the positive control group was shorter than the negative control group due to the administration of tranexamic acid which served as a coagulation agent. Tranexamic acid works as an anti-fibrinolytic agent by 
inhibiting the breakdown of polymer fibrin by plasmin, so that hemostasis can occur more effectively (Levy et al., 2018). The treatment group of Broccoli extract dosages of 20,40 , and $60 \mathrm{mg} / \mathrm{kg}$ BW yielded the averaging time of $122.60 \pm 29.535 ; 102.40 \pm 9.607 ;$ and $90.40 \pm 3.845$ seconds, respectively. Comparison of bleeding time for all groups is presented in Table II, while the comparison for average bleeding time is presented in Figure 1.

Table II. Bleeding time for all groups

\begin{tabular}{ccccccc}
\hline \multirow{2}{*}{ Group } & \multicolumn{5}{c}{ Bleeding time (s)/mice } & Mean \\
\cline { 2 - 6 } & 1 & 2 & 3 & 4 & 5 & \pm SD \\
\hline Negative & 163 & 202 & 164 & 192 & 194 & 183.00 \\
control & & & & & & \pm 18.193 \\
Positive & 65 & 73 & 84 & 73 & 74 & 73.80 \\
control & & & & & & \pm 6.76 \\
Broccoli & 102 & 122 & 173 & 101 & 115 & 122.60 \\
Extract 20 & & & & & & \pm 29.535 \\
mg/Kg BW & & & & & & \\
Broccoli & 93 & 102 & 93 & 110 & 114 & 102.40 \\
Extract 40 & & & & & & \pm 9.607 \\
mg/Kg BW & & & & & & \\
Broccoli & 85 & 90 & 89 & 93 & 92 & 90.40 \\
Extract 60 & & & & & & \pm 3.845 \\
mg/Kg BW & & & & & & \\
\hline
\end{tabular}

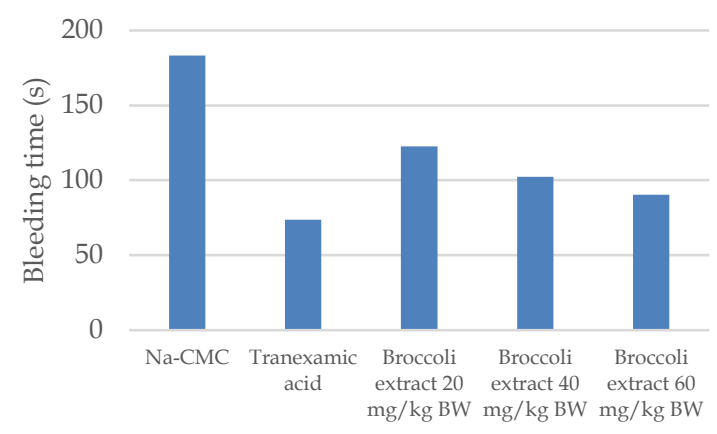

Figure 1. Comparison of average bleeding time for all test groups

This result indicated that bleeding time of the broccoli extract treatment group was shorter than the negative control. This is due to the presence of substances in the extracted content of broccoli which functions as a coagulation consisting of vitamin K (Janarthanan \& Kumar, 2013). Vitamin K has an important role in clotting physiology, including as a cofactor for carboxylation of glutamate residues in post-synthesis modification of proteins to form unusual carboxyglutamate amino acids (Rishavy \& Bekner, 2012).

Bleeding time was observed to see the effect of the test material on the formation of temporary coagulation plugs, namely platelet phase hemostasis (primary hemostasis). This will occur if there are desquamation and small injuries to the blood vessels. Primary hemostasis involves the intima of blood vessels and platelets. Wounds will induce vasoconstriction and platelet plugs. The time from the start of the wound to the formation of a temporary coagulation plug in the wound area is called the bleeding time. The effect is shown by the shorter bleeding time after giving test material (Periayah et al., 2017).

\section{Statistical analysis}

Determination of the normality of data distribution on the percentage of stopping bleeding is done using the Shapiro Wilk test. The analysis showed that the data were normally distributed $(p>0.05)$. The test was then continued with a variant homogeneity test for the percentage of cessation of bleeding using the Levene test. The results obtained indicate a significance value (sig.) > 0.05 so that the percentage of data obtained is declared homogeneous. The test then continued with the one-way ANOVA test.

Percentage data of bleeding cessation show significance value $p<0.05$. These results indicate that there are differences between each treatment. This indicates that there was a process of stopping bleeding in the rat's tail due to treatment with broccoli extract and positive control. The test then continued with post hoc using the LSD test to see the comparison of differences between treatment groups in more detail.

The positive control group and broccoli extract with concentrations of 40 and $60 \mathrm{mg} / \mathrm{kg}$ BW showed a significant difference in stopping bleeding $(p<0.005)$ compared to the negative control. While broccoli extract 
with a concentration of $20 \mathrm{mg} / \mathrm{kg}$ BW did not show any significant difference compared to negative controls. There were significant differences between positive control with the broccoli extract group 20 and $40 \mathrm{mg} / \mathrm{kg}$ BW ( $\mathrm{p}<0.005)$, while in the $60 \mathrm{mg} / \mathrm{kg}$ BW group there was no significant difference $(p>0.005)$. These results indicate that broccoli extract with a concentration of 60 $\mathrm{mg} / \mathrm{kg}$ BW is not so different when compared to the tranexamic acid in reducing bleeding time. These results reinforce the notion that broccoli extract can be an alternative to be considered as a substitute for tranexamic acid as a hemostatic agent. The LSD test results from each group are presented in Table III.

Table III. Post Hoc LSD test results for each test group

\begin{tabular}{|c|c|c|c|}
\hline \multicolumn{2}{|c|}{ Comparison Group } & \multirow{2}{*}{$\begin{array}{c}\text { Sig } \\
0.000\end{array}$} & \multirow{2}{*}{$\begin{array}{l}\text { Conclusion } \\
\text { Different }\end{array}$} \\
\hline Negative & Positive Control & & \\
\hline Control & Group & & \\
\hline \multirow[t]{3}{*}{$\begin{array}{l}\text { Group (Na- } \\
\text { CMC) }\end{array}$} & $\begin{array}{l}\text { Extract } 20 \mathrm{mg} / \mathrm{Kg} \\
\text { BW }\end{array}$ & 0.006 & No different \\
\hline & $\begin{array}{l}\text { Extract } 40 \mathrm{mg} / \mathrm{Kg} \\
\text { BW }\end{array}$ & 0.000 & Different \\
\hline & $\begin{array}{l}\text { Extract } 60 \mathrm{mg} / \mathrm{Kg} \\
\text { BW }\end{array}$ & 0.000 & Different \\
\hline \multirow{5}{*}{$\begin{array}{l}\text { Positive } \\
\text { Control } \\
\text { Group } \\
\text { (Tranexamic } \\
\text { acid) }\end{array}$} & Negative Control & 0.000 & Different \\
\hline & Group & & \\
\hline & $\begin{array}{l}\text { Extract } 20 \mathrm{mg} / \mathrm{Kg} \\
\text { BW }\end{array}$ & 0.000 & Different \\
\hline & $\begin{array}{l}\text { Extract } 40 \mathrm{mg} / \mathrm{Kg} \\
\text { BW }\end{array}$ & 0.012 & Different \\
\hline & $\begin{array}{l}\text { Extract } 60 \mathrm{mg} / \mathrm{Kg} \\
\text { BW }\end{array}$ & 0.127 & No different \\
\hline \multirow{4}{*}{$\begin{array}{l}\text { Broccoli } \\
\text { Extract } 20 \\
\text { mg/Kg BW }\end{array}$} & Negative Control & 0.006 & No different \\
\hline & $\begin{array}{l}\text { Group } \\
\text { Positive Control } \\
\text { Group }\end{array}$ & 0.000 & Different \\
\hline & $\begin{array}{l}\text { Extract } 40 \mathrm{mg} / \mathrm{Kg} \\
\text { BW }\end{array}$ & 0.003 & Different \\
\hline & $\begin{array}{l}\text { Extract } 60 \mathrm{mg} / \mathrm{Kg} \\
\text { BW }\end{array}$ & 0.006 & Different \\
\hline \multirow{5}{*}{$\begin{array}{l}\text { Broccoli } \\
\text { Extract } 40 \\
\text { mg/Kg BW }\end{array}$} & Negative Control & 0.000 & Different \\
\hline & Group & & \\
\hline & $\begin{array}{l}\text { Positive Control } \\
\text { Group }\end{array}$ & 0.012 & Different \\
\hline & $\begin{array}{l}\text { Extract } 20 \mathrm{mg} / \mathrm{Kg} \\
\text { BW }\end{array}$ & 0.003 & Different \\
\hline & $\begin{array}{l}\text { Extract } 60 \mathrm{mg} / \mathrm{Kg} \\
\text { BW }\end{array}$ & 0.010 & Different \\
\hline \multirow{4}{*}{$\begin{array}{l}\text { Broccoli } \\
\text { Extract } 60 \\
\text { mg/Kg BW }\end{array}$} & Negative Control & 0.000 & Different \\
\hline & $\begin{array}{l}\text { Positive Control } \\
\text { Group }\end{array}$ & 0.127 & No different \\
\hline & $\begin{array}{l}\text { Extract } 20 \mathrm{mg} / \mathrm{kg} \\
\text { BW }\end{array}$ & 0.006 & Different \\
\hline & $\begin{array}{l}\text { Extract } 40 \mathrm{mg} / \mathrm{kg} \\
\text { BW }\end{array}$ & 0.010 & Different \\
\hline
\end{tabular}

\section{CONCLUSION}

Based on the results of this study it can be concluded that the extract of broccoli at a dose of $60 \mathrm{mg} / \mathrm{kg}$ BW gives the best results as hemostatic, while the effect is almost similar to the positive control group. Further study needed for further observe the wound healing effect of broccoli extract and from its active metabolites.

\section{ACKNOWLEDGMENT}

The author thanks to Pharmacology Laboratory of Sekolah Tinggi Ilmu Kesehatan Mitra Bunda Persada Batam, which has provided facilities and infrastructure so that this research can run smoothly.

\section{REFERENCES}

Auwal, M.S., Saka, S., Mairiga, I.A., Sanda, K.A., Shuaibu, A., \& Ibrahim, A. (2014). Preliminary phytochemical and elemental analysis of aqueous and fractionated pod extracts of Acacia nilotica (Thorn mimosa). Veterinary Research Forum, 5(2), 95-100.

Batool, R., Khan, M.R., Sajid, M., Ali, S., \& Zahra, Z. (2019). Estimation of phytochemical constituents and in vitro antioxidant potencies of Brachychiton populneus (Schott \& Endl.) R.Br. BMC Chemistry, 13(1), 32. doi: 10.1186/s13065-0190549-z

Chauhan, E.S., Tiwari, A., \& Singh, A. (2016). Phytochemical screening of red cabbage (Brassica oleracea) powder and juice - A comparative study. Journal of Medicinal Plants Studies, 4(5), 196-199.

Chen, L., Deng, H., Cui, H., Fang, J., Zuo, Z., Deng, J., Li, Y., Wang, X., \& Zhao, L. (2018). Inflammatory responses and inflammation-associated diseases in organs. Oncotarget, 9(6), 7204-7218. doi: 10.18632 /oncotarget.23208

Curnow, J., Pasalic, L., \& Favaloro, E.J. (2016). Why Do Patients Bleed?. The Surgery Journal, 2(1), 29-43. doi: 10.1055/s-0036-1579657 
Guo, S. \& DiPietro, L.A. (2010). Factors Affecting Wound Healing. Journal of Dental Research, 89(3), 219229. doi: $10.1177 / 0022034509359125$

Hossain, M.A., Al-Raqmi, K.A.S., Al-Miijzy, Z.H., Weli, A.M., \& Al-Riyami, Q. (2013). Study of total phenol, flavonoids contents and phytochemical screening of various leaves crude extracts of locally grown Thymus vulgaris. Asian Pacific Journal of Tropical Biomedicine, 3(9), 705-710. doi: 10.1016/S22211691(13)60142-2

Hussain, M., Debnath, B., Qasim, M., Bamisile, B.S., Islam, W., Hameed, M.S., Wang, L., \& Qiu, D. (2019). Role of Saponins in Plant Defense Against Specialist Herbivores. Molecules, 24(11), 2067. doi: 10.3390/molecules24112067

Janarthanan, M. \& Kumar, M.S. (2013). Qualitative and Quantitative Analysis of Phytochemical Studies on Selected Seaweeds Acanthopora Spicifera and Sargassum Wightii. International Journal of Engineering Research and Development, 7(3), 11-15.

Levy, J.H., Koster, A., Quinones, Q.J., Milling, T.J., \& Key, N.S. (2018). Antifibrinolytic Therapy and Perioperative Considerations. Anesthesiology, 128(3), 657-670. doi: 10.1097/ALN.0000000000001997

Liu, J., Lin, S., Wang, Z., Wang, C., Wang, E., Zhang, Y., \& Liu, J. (2012). Pharmacognosy and Pharmacobiotechnology. Maryland, United States: Willimans \& Wilkins.

Mageney, V., Neugart, S., \& Albach, D.C. (2017). A Guide to the Variability of Flavonoids in Brassica oleracea. Molecules, 22(2), 252. doi: 10.3390/molecules22020252

Panche, A.N., Diwan, A.D., \& Chandra, S.R. (2016). Flavonoids: an overview. Journal of Nutritional Science, 5, 47. doi: 10.1017/jns.2016.41

Periayah, M.H., Halim, A.S., \& Saad, A.Z.M. (2017). Mechanism Action of Platelets and Crucial Blood Coagulation Pathways in Hemostasis. International Journal of Hematology-Oncology and Stem Cell Research, 11(4), 319-327.

Pierce, A. \& Pittet, J.F. (2014). Practical understanding of hemostasis and approach to the bleeding patient in the OR. Advances in Anesthesia, 32(1), 1-21. doi: 10.1016/j.aan.2014.08.009
Raiola, A., Errico, A., Petruk, G., Monti, D.M., Barone, A., \& Rigano, M.M. (2017). Bioactive Compounds in Brassicaceae Vegetables with a Role in the Prevention of Chronic Diseases. Molecules, 23(1), 15. doi: 10.3390/molecules23010015

Rishavy, M.A. \& Beckner, K.L. (2012). Vitamin K Oxygenation, Glutamate Carboxylation, and Processivity: Defining the Three Critical Facets of Catalysis by the Vitamin K-Dependent Carboxylase. Advances in Nutrition, 3(2), 135148. doi: 10.3945/an.111.001719

Sacher, R.A. (2012). Tinjauan Klinis Hasil Pemeriksaan Laboratorium. 11 th Edition. Jakarta, Indonesia: EGC.

Saghazadeh, S., Rinoldi, C., Schot, M., Kashaf, S.S., Sharifi, F., Jalilian, E., Nuutila, K., Giatsidis, G., Mostafalu, P., Derakhshandeh, H., Yue, K., Swieszkowski, W., Memic, A., Tamayol, A., \& Khademhosseini, A. (2018). Drug Delivery Systems and Materials for Wound Healing Applications. Advanced Drug Delivery Reviews, 127, 138-166. doi: 10.1016/j.addr.2018.04.008

Samanta, R., Pattnaik, A.K., Pradhan, K.K., Mehta, B.K., Pattanayak, S.P., \& Banerjee, S. (2016). Wound Healing Activity of Silibinin in Mice. Pharmacognosy Research, 8(4), 298-302. doi: 10.4103/0974-8490.188880

Sherwood, L. (2015). Fisiologi Manusia dari Sel ke Sistem. $9^{\text {th }}$ Edition (pp. 430-431). Jakarta, Indonesia: EGC.

United States Department of Agriculture. (2012). Broccoli, Onion, Garlic and Coriander. In National Nutrient Database for Standard Reference (Ch. 26). United States: United States Department of Agriculture Nutrient Data Laboratory and Health.

Xu, Y., Xu, W., Wang, A., Meng, H., Wang, Y., Liu, S., Li, R., Lu, S., \& Peng, J. (2019). Diagnosis and treatment of traumatic vascular injury of limbs in military and emergency medicine: A systematic review. Medicine, 98(18), 15406. doi: 10.1097/MD.0000000000015406

Yuan, H., Ma, Q., Ye L., \& Piao, G. (2016). The Traditional Medicine and Modern Medicine from Natural Products. Molecules, 21(5), 559. doi: 10.3390/molecules21050559 